Central Washington University

ScholarWorks@CWU

6-1999

\title{
Use of anal gland secretion to distinguish the two beaver species Castor canadensis and $\mathrm{C}$. fiber
}

Frank Rosell

Telemark College

Lixing Sun

Central Washington University, lixing@cwu.edu

Follow this and additional works at: https://digitalcommons.cwu.edu/biology

Part of the Biology Commons

\section{Recommended Citation}

Rosell, F. \& Sun, L. (1999). Use of anal gland secretion to distinguish the two beaver species Castor canadensis and C. fiber. Wildlife Biology, 5(2), 119-123.

This Article is brought to you for free and open access by the College of the Sciences at ScholarWorks@CWU. It has been accepted for inclusion in Biology Faculty Scholarship by an authorized administrator of ScholarWorks@CWU. For more information, please contact scholarworks@cwu.edu. 


\title{
Use of anal gland secretion to distinguish the two beaver species Castor canadensis and $C$. fiber
}

\author{
Frank Rosell \& Lixing Sun
}

\begin{abstract}
Rosell, F. \& Sun, L. 1999: Use of anal gland secretion to distinguish the two beaver species Castor canadensis and C. fiber. - Wildl. Biol. 5: 119-123.

Introduced North American beavers Castor canadensis pose a potential threat to the continuing recovery of Eurasian beaver $C$. fiber populations in several European countries. For management purposes, it is necessary to be able to identify and distinguish the two species. This, however, is difficult because the two species are morphologically, ecologically and behaviourally similar. To find a method for species identification, we examined the possibility of using anal gland secretion (AGS) collected from the two beaver species. We asked 20 inexperienced volunteers to inspect the colour and viscosity of the AGS. When we provided the volunteers with the sex of each beaver and descriptions of the colour and viscosity of AGS from males and females of the two species, all volunteers could $100 \%$ correctly identify the two species. We therefore conclude that the colour and viscosity of the AGS can be used for a quick and easy identification of the two beaver species.
\end{abstract}

Key words: Castor canadensis, Castor fiber, Norway, sex determination, species determination, USA

Frank Rosell, Telemark College, Department of Environmental Sciences, $N$ 3800 B $\phi$, Norway - e-mail: Frank.Rosell@hit.no

Lixing Sun, Department of Biological Sciences, Central Washington University, Ellensburg, WA 98930, USA

Received 3 April 1998, accepted 25 February 1999

Associate Editor: Henrik Andrén

The two extant species of the genus Castor, the Eurasian beaver $C$. fiber and the North American beaver C. canadensis, are similar both morphologically and behaviourally (e.g. Wilsson 1971, Patenaude 1984, Novak 1987) and were once classified as one species (Hill 1982). The two-species status was finally established after Lavrov \& Orlov (1973) found that the diploid chromosome number is 48 in C. fiber and 40 in $C$. canadensis, following Robertsonian fusion of eight chromosome pairs in $C$. canadensis.
Introductions of North American beavers, reintroductions of Eurasian beavers and translocations of the two species have played an important role in the recovery of beavers in Eurasia (see Nolet \& Rosell 1998) and also resulted in several unexpected ecological consequences. The North American beaver was introduced into Finland during 1935-1937 and into several other European countries at various times in the 20th century (see Nolet \& Rosell 1998). Most of the introductions were successful, and sever- 
al populations have since thrived (e.g. Lahti 1995, Nolet \& Rosell 1998). Interspecific competition may have profound effects on the population dynamics of competing species, and influence the species' distribution and evolution (Begon, Harper \& Townsend 1990). Field observations suggest that the North American beaver might be a stronger competitor than the Eurasian beaver (Ermala, Helminen \& Lahti 1989). Currently, North American beavers can be found along the Seine in France, in Russian Karelia, and may also exist in Austria, the Czech Republic, Hungary, Poland and Slovakia (see Sieber 1989, Kollar \& Seiter 1990, Nolet \& Rosell 1998). Since beavers are capable of undergoing long-distance dispersal (Sun, Müller-Schwarze \& Schulte in press) time may be the only problem before the North American beavers in Finland invade other Nordic countries. It has become a major task for wildlife managers there to prevent this from happening (Nummi 1996). Also, other sporadic populations of the North American beaver should be exterminated before they grow and spread further. To handle these problems, identification of the two beaver species is essential. The only reliable method currently available is to check for the chromosome number (Lavrov \& Orlov 1973). This method is slow and expensive and requires support from chromosome experts and sophisticated technology. Managers of beaver populations need a quick and easy alternative to identify and distinguish the two beaver species.

Beavers live in family groups, which defend territories against other beavers (e.g. Bradt 1938, Djoshkin \& Safonow 1972, Nolet \& Rosell 1994, Rosell \& Nolet 1997). Both sexes of the two species scent mark the borders of their territories with secretions from the castor sacs and/or the anal glands (e.g. Hodgdon 1978, Svendsen 1980, Buech 1995, Rosell \& Bergan 1999, Rosell, Bergan \& Parker 1998). The anal gland is a holocrine secretory gland, but the castor sac is only a pocket lined with a layer of nonsecretory epithelium (Svendsen 1978, Valeur 1988). The lipid composition, colour, viscosity and odour of anal gland secretion (AGS) can be used for sexing beavers (Grønneberg 1979, Grønneberg \& Lie 1984, Schulte, Müller-Schwarze \& Sun 1995). For the Eurasian beaver, the AGS is a thick paste of a greyish colour with an unpleasant odour in females, and is an oily fluid with a whitish or pale straw colour and a stronger and different odour in males (Owesen 1979, Grønneberg \& Lie 1984, Valeur 1988). The variation in the composition of AGS samples collected from individuals of the same sex is small, and the appearance of the AGS is independent of live- or deadtrapped beavers (Grønneberg \& Lie 1984). For the North American beaver, the AGS of the two sexes show a consistent difference regardless of age: it is brown and viscous in males, but it is whitish or light yellow and runny in females (Schulte et al. 1995). In this study, we examined the possibility of using the colour and viscosity of the AGS as a quick and easy way to identify and distinguish the two beaver species.

\section{Material and methods}

We collected 46 fresh AGS samples from legally killed Eurasian beavers ( 23 males and 23 females) during spring (March-April) 1997 in the municipality of $B \emptyset$, the county of Telemark, Norway. The animals were sexed by presence or absence of the os penis (Osborn 1955). We assigned beavers to three age classes based on body weight (see Hartman 1992): 1-year-olds (< 12 months, $0-10 \mathrm{~kg}$ ), 2-yearolds (12-24 months, $10-15 \mathrm{~kg}$ ), and $\geq 3$-year-olds ( $\geq 24$ months, $\geq 15 \mathrm{~kg}$ ). We cut the anal glands open with a surgical blade and compared the colour of male and female AGS using the standardised colour chart system, PANTONE (Letraset) (Schulte et al. 1995). We placed secretion samples in glass vials and stored them in a freezer $\left(-20^{\circ} \mathrm{C}\right)$. The 46 secretion samples were brought frozen to a laboratory in USA. Twenty samples were randomly selected, thawed at room temperature and used in the experiment described below.

We also collected 19 AGS samples from livetrapped North American beavers (10 males and 9 females) in different age classes near Ellensburg in the state of Washington, and in the state of New York, USA, during autumn and spring in the years 19951997. Live-trapped beavers were anaesthetised with a 1:2 mixture by volume of xylazine and ketamine ( 0.67 and $6.7 \mathrm{mg} / \mathrm{kg}$ body mass, respectively). We collected AGS by palpating anal gland and papillae. We placed all samples in glass vials and stored them in a freezer at $-20^{\circ} \mathrm{C}$. We determined the age, sex and colour of AGS by similar methods as used for the Eurasian beaver.

\section{Experiment: identification of species by visual cues}

We put ca $0.5 \mathrm{ml}$ of each AGS sample into a $10-\mathrm{ml}$ 
Table 1. Comparison of the values from a standardised colour chart ${ }^{a}$ for the anal gland secretion by age and sex for 20 Eurasian beavers from Norway ${ }^{b} 1997,19$ North American beavers from Washington/New York State ${ }^{c}$ 1995-1997 and 15 from New York State ${ }^{d} 1992-1994$.

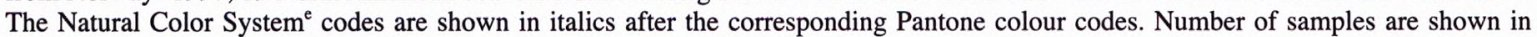
brackets.

\begin{tabular}{|c|c|c|c|c|}
\hline $\mathrm{Age}^{\mathrm{f}}$ & Sex & C. fiber $^{\mathrm{b}}$ & C. canadensis ${ }^{c}$ & C. canadensis ${ }^{\mathrm{d}}$ \\
\hline 1-year-old & q & $\begin{array}{l}4545 S 1005-Y 20 R(2) \\
452 S 3005-Y 20 R(1) \\
454 S 2005-Y 20 R(1)\end{array}$ & $458 S 2040-Y(1)$ & $\begin{array}{l}458 S 2040-Y(1), \\
459 S 1030-Y(2), \\
461 S 1030-Y(1)\end{array}$ \\
\hline 1-year-old & 0 & $\begin{array}{l}458 S 2040-Y(1), \\
610 S 1030-Y(2)\end{array}$ & $465 S 3020-Y 40 R$ & $465 S 3020-Y 40 R(3)$ \\
\hline 2-year-old & q & $\begin{array}{l}455 S 6030-Y(3) \\
413 S 2005-G 50 Y(1)\end{array}$ & 458 S $2040-Y(1)$ & - \\
\hline 2-year-old & 0 & $\begin{array}{l}459 \text { S 1030-Y(1), } \\
610 \text { S } 1030-Y(1)\end{array}$ & $465 S 3020-Y 40 R(3)$ & - \\
\hline$\geq 3$-year-old & $q$ & $\begin{array}{l}455 S 6030-Y(1) \\
455^{8} S 6030-Y I \\
413^{8} S 2005-G 50 Y(1)\end{array}$ & $\begin{array}{l}458 S 2040-Y(3), \\
459 S 1030-Y(4)\end{array}$ & $\begin{array}{l}458 \text { S } 2040-Y(1), \\
459 S 1030-Y(1) \text {, } \\
461 \text { S } 1030-Y(1)\end{array}$ \\
\hline$\geq 3$-year-old & o & $\begin{array}{l}458 \text { S } 2040-Y(1) \\
459 S 1030-Y(3) \\
609 S 1030-Y(1)\end{array}$ & $465 S 3020-Y 40 R(6)$ & $\begin{array}{l}465 S 3020-Y 40 R \text { (4), } \\
466 S 3020-Y 30 R \text { (1) }\end{array}$ \\
\hline
\end{tabular}

a Colour formula guide 1000, Pantone, Inc. 590 Commerce Boulevard, Carlstadt, New Jersey, 07072-3098, USA. We used the coated paper in the colour formula guide.

b Results from this study (dead-trapped animals).

c Results from this study (live-trapped animals).

d Results from Schulte et al. (1995) (live-trapped animals).

e Natural Color System (NCS), Skandinaviska Färginstitutet AB, Box 49022, S-100 28 Stockholm.

f We assigned beavers to age classes based on body weight and size (see 'Material and methods' and Schulte 1993).

$g$ This female had different colours of secretion in the two anal glands.

plastic test tube and pooled the 20 AGS samples randomly selected from the 46 Eurasian beavers with the 19 AGS samples from North American beavers. After randomising the 39 samples, we asked 20 volunteers (10 men, 10 women; age range: $18-40$; all inexperienced with beaver secretions) to classify these samples into four groups, corresponding to the two sexes of the two species. We provided the volunteers with descriptions of the colour and viscosity of AGS from the males and females of the two species, and also information about the sex of the beaver, from which each secretion sample was collected. The experiment was carried out under a fluorescent light (several 40 w bulbs) in a room with a white sheet as the background.

\section{Results}

\section{Colour and viscosity of the AGS of Eurasian and North American beavers}

The AGS characteristics of our samples were according to earlier findings. The sex difference in the colour of AGS in the Eurasian and North American beaver was consistent and was not affected by age (Table 1).

\section{Species identification using visual cues}

In the experiment, we pooled data because there was no significant difference in identification ability between male and female subjects. Volunteers could $100 \%$ accurately classify the 39 samples into four groups corresponding to the two sexes of the two species using the colour and viscosity of AGS.

\section{Discussion}

Several researchers have noticed the sexual dimorphism in colour and viscosity of AGS in the Eurasian beaver (Owesen 1979, Grønneberg \& Lie 1984, Valeur 1988) and the North American beaver (Allred 1986, Schulte et al. 1995). Furthermore, in the North American beaver, the chemical composition of the AGS changes little as an individual grows older or by season, and it does not change if an individual moves to a new site (Sun 1996). This could also be true for the Eurasian beaver, although no data to support this are currently available. The consistency in the colour and viscosity of the AGS may be due to the stability of the chemical composition of the AGS. When we provided the volunteers with the sex of each beaver and descriptions of the colour and viscosity of AGS from the males and females of the two species, all 
volunteers could $100 \%$ correctly identify the two species.

Sexing live beavers is easy by palpating for the presence or absence of the os penis (Osborn 1955). However, the sex of young beavers may be difficult to determine in the field (Osborn 1955, Larson \& Knapp 1971, Brady \& Svendsen 1981), especially for inexperienced researchers. In this situation, the species of the young beavers in question can be determined by identifying the species of an older beaver living in the same colony because both species live in discrete family units and extremely young beavers do not wander far away from their lodges.

\section{Management implications}

The two main threats for the endemic Eurasian beaver in Europe are habitat destruction and the spreading of introduced North American beavers (Nolet \& Rosell 1998). The North American beaver has a greater ecological flexibility, survives better under severe climatic conditions, adapt more easily to substitute foods and regulate hydrological regimes of water bodies better with a stronger building instinct than its Eurasian counterpart (Danilov \& Kan'shiev 1983). The North American beaver is also more fecund (Hill 1982) with a significantly larger colony size $(5.2 \pm 1.4 \mathrm{SD})$ than Eurasian beaver $(3.8 \pm 1.0$ SD) (Rosell \& Parker 1995). Dispersal of the North American beaver from Finland is thus a pending threat to the endemic Scandinavian population of the Eurasian beaver. Similar pending threats also call for control of the North American beaver in several other areas in Europe. Because beavers are relatively easy to trap, this threat can be relieved through extensive trapping. The effectiveness of this management practice, however, depends on the availability of a quick and easy method to identify and distinguish the two species. Our results showed that the colour and viscosity of the AGS can be used for a quick and easy identification of the two beaver species.

Acknowledgements - we specially thank F. Bergan for discovering the possible difference in the AGS between the two species. We thank G. Hartman, J. Heggenes, H. Parker and B.A. Nolet for review comments, F. Bergan, T.A. Hermansen, B. Hovde, Ø. Steifetten, M. Stærk, G. Sørløkk and G. Uren for help in collection and dissection of Eurasian beavers, and $\mathrm{R}$. Li for help in the laboratory. The completion of this project would not have been possible without extensive involvement of numerous biology students at Central Washington University in beaver trapping and experimentation. The study was supported financially by the
Norwegian Directorate for Nature Management and the County Conservation Departments in Aust-Agder, Hedmark, Oppland, Oslo \& Akershus, Sør-Trøndelag, VestAgder, Vestfold and Østfold, and by Central Washington University Research Funds.

\section{References}

Allred, M. 1986: Beaver behavior: architect of fame \& bane! - Happy Camp, California, Naturegraph, USA, 110 pp.

Begon, M., Harper, J.L. \& Townsend, C.R. 1990: Ecology: individuals, populations, and communities. - Second Edition, Blackwell Scientific Publications, USA, 945 pp.

Bradt, G.W. 1938: A study of beaver colonies in Michigan. - Journal of Mammalogy 19: 139-162.

Brady, C.A. \& Svendsen, G.E. 1981: Social behaviour in a family of beaver, Castor canadensis. - Biology of Behaviour 6: 99-114.

Buech, R.R. 1995: Sex difference in behavior of beavers living in near-boreal lake habitat. - Canadian Journal of Zoology 73: 2133-2143.

Danilov, P.I. \& Kan'shiev, V.Y. 1983: The state of populations and ecological characteristics of European (Castor fiber L.) and Canadian (Castor canadensis K.) beavers in the northwestern USSR. - Acta Zoologica Fennica 174: 95-97.

Djoshkin, W.W. \& Safonow, W.G. 1972: Die Biber der alten und neuen Welt. - A. Ziemsen Verlag, Wittenberg, 168 pp. (In German).

Ermala, A., Helminen, M. \& Lahti, S. 1989: Majaviemme levinneisyyden ja runsauden vaihteluista sekä tulevaisuuden näkymistä. (In Finnish with English summary: Some aspects of the occurrence, abundance and future of the Finnish beaver population.) - Suomen Riista 35: 108118.

Grønneberg, Т.Ø. 1979: Analysis of a wax ester fraction from anal gland secretion of beaver (Castor fiber) by chemical ionization mass spectrometry. - Chemica Scripta 13: $56-58$.

Grønneberg, T.Ø. \& Lie, T. 1984: Lipids of the anal gland secretion of beaver (Castor fiber). - Chemica Scripta 24: 200-203.

Hartman, G. 1992: Age determination of live beaver by dental x-ray. - Wildlife Society Bulletin 20: 216-220.

Hill, E.P. 1982: Beaver (Castor canadensis). - In: Chapman, J.A. \& Feldhamer, G.A. (Eds.); Wild mammals of North America-Biology, Management, and Economics. The John Hopkins University Press, Baltimore and London, pp. 256-281.

Hodgdon, H.E. 1978: Social dynamics and behavior within an unexploited beaver (Castor canadensis) population. - PhD thesis, University of Massachusetts, Amherst, USA, $292 \mathrm{pp}$.

Kollar, H.P. \& Seiter, M. 1990: Biber in den Donau-Auen 
östlich von Wien. Eine erfolgreiche Wiederansiedlung. Verein für Ökologie und Umweltforschung, Wien, 75 pp. (In German).

Lahti, S. 1995: Bäverns utbredning i Finland från 1980talet fram till i dag. - In: Ermala, A. \& Lahti, S. (Eds.); The Third Nordic Beaver Symposium, 15.-17.9. 1992, Iiomats, Finland Finnish Game and Fisheries Research Institute, Helsinki, pp. 41-43. (In Swedish).

Larson, J.S. \& Knapp, S.J. 1971: Sexual dimorphism in beaver neutrophils. - Journal of Mammalogy 52: 212215.

Lavrov, L.S. \& Orlov, V.N. 1973: Karyotypes and taxonomy of modern beavers (Castor, Castoridae, Mammalia).) - Zoologische Zhurnal 52: 734-742. (In Russian with English summary).

Nolet, B.A. \& Rosell, F. 1994: Territoriality and time budgets in beavers during sequential settlement. - Canadian Journal of Zoology 72: 1227-1237.

Nolet, B.A. \& Rosell, F. 1998: Comeback of the beaver Castor fiber: an overview of old and new conservation problems. - Biological Conservation 83: 165-173.

Novak, M. 1987: Beaver. - In: Novak, M., Baker, J.A., Obbard, M.E. \& Malloch, B. (Eds.); Wild Furbearer Management and Conservation in North America. Ontario, Ontario Ministry of Natural Resources, USA, pp. 283-312.

Nummi, P. 1996: Wildlife introductions to mammal-deficient areas: the Nordic countries. - Wildlife Biology 2: 221-226.

Osborn, D.J. 1955: Techniques of sexing beaver, Castor canadensis. - Journal of Mammalogy 36: 141-142.

Owesen, A. 1979: I beverskog. - Gyldendal Norsk Forlag, Oslo, 120 pp. (In Norwegian).

Patenaude, F. 1984: The ontogeny of behavior of free-living beavers (Castor canadensis). - Zeitung Tierpsychologie 66 : 33-44.

Rosell, F. \& Bergan, F. 1998: Free-ranging Eurasian beavers, Castor fiber, deposit anal gland secretion when scent marking. - Canadian Field-Naturalist 112: 532535.

Rosell, F., Bergan, F. \& Parker, H. 1998: Scent-marking in the Eurasian beaver (Castor fiber) as a means of territory defence. - Journal of Chemical Ecology 24: 207-219.

Rosell, F. \& Nolet, B.A. 1997: Factors affecting scentmarking behavior in the Eurasian beaver (Castor fiber). - Journal of Chemical Ecology 23: 673-689.

Rosell, F. \& Parker, H. 1995: Forvaltning av bever: dagens tilstand og fremtidig behov. (In Norwegian with English summary: Beaver management: present practice and Norway's future needs.) - Report, Telemark College, B $\varnothing$ in Telemark, Norway, 137 pp.

Schulte, B.A. 1993: Chemical communication and ecology of the North American beaver (Castor canadensis). - PhD thesis, State University New York, Syracuse, USA, 194 pp.

Schulte, B.A., Müller-Schwarze, D. \& Sun, L. 1995: Using anal gland secretion to determine sex in beaver. - Journal of Wildlife Management 59: 614-618.

Sieber, J. 1989: Biber in Oberösterreich: eine aktuelle Bestandsaufnahme an Inn und Salzach. - Jahrbücher Oberösterreichischer Museum-Verein 134: 277-285. (In German).

Sun, L. 1996: Chemical Kin Recognition in the Beaver (Castor canadensis): Behavior, Relatedness and Information Coding. - PhD thesis, State University New York, Syracuse, USA, 184 pp.

Sun, L, Müller-Schwarze, D. \& Schulte, B.A. in press: Dispersal pattern and effective population size of the beaver. - Journal of Mammalogy.

Svendsen, G.E. 1978: Castor and anal glands of the beaver (Castor canadensis). - Journal of Mammalogy 59: 618620.

Svendsen, G.E. 1980: Patterns of scent-mounding in a population of beaver (Castor canadensis). - Journal of Chemical Ecology 6: 133-148.

Valeur, P. 1988: Beverens territorial-adferd som populasjonsregulerende faktor. (In Norwegian with English summary: Territorial behavior as factor in regulation of populations in beaver.) - Fauna 41: 20-34.

Wilsson, L. 1971: Observations and experiments on the ethology of the European Beaver (Castor fiber L.). Viltrevy 8: 115-306. 